\title{
Three new species of Phyllocoptinae mites (Prostigmata: Eriophyidae) associated with ornamental plants in Brazil
}

\author{
DENISE NAVIA ${ }^{1} \&$ CARLOS H. W. FLECHTMANN ${ }^{2}$ \\ ${ }^{1}$ Researcher, Embrapa Recursos Genéticos e Biotecnologia, Laboratório de Quarentena Vegetal, C. P. 02372, 70.770-900 Brasília, \\ DF, Brazil.E-mail: navia@cenargen.embrapa.br \\ ${ }^{2}$ CNPq-Brazil Researcher, Universidade de São Paulo/ESALQ, Departamento de Entomologia, Fitopatologia e Zoologia Agrícola, \\ 13.418-900 Piracicaba, SP, Brazil.E-mail: chwflech@carpa.ciagri.usp.br
}

\begin{abstract}
Three new species of Phyllocoptinae mites (Prostigmata: Eriophyidae) from Brazil namely Acaricalus souzae n. sp. (Acaricalini), from common morning glory, Ipomoea purpurea (Convolvulaceae); Aculops fenestratus n. sp. (Anthocoptini), from royal poinciana or flamboyant, Delonix regia (Fabaceae); and Porcupinotus costaspinosus n. sp. (Anthocoptini), from Abarema cochliacarpos (Mimosaceae) are described. The eriophyoid mite species were causing no apparent damage.
\end{abstract}

Key words: Acari, Eriophyoidea, plant feeding mites, taxonomy, South America

\section{Introduction}

The transportation of ornamental plants represents an important way for the dissemination of plant pests around the world. Phytosanitary aspects of this group of plants must be further investigated. Phytophagous mites, including Eriophyoidea, are among pests of ornamental plants. In this study three new eriophyid species infesting ornamental plants in Brazil are descibed. The common morning glory, Ipomoea purpurea (L.) Roth. (Convolvulaceae), is an annual deciduous vine with purple flowers and probably originates from Mexico and is pantropically cultivated (Connecticut Botanical Society 2005). The royal poinciana or flamboyant, Delonix regia (Bojer ex Hook.) Raf. (Fabaceae), is a deciduous tropical tree with fern-like leaves that originates from Madagascar and is largely cultivated throughout the tropics (Vozzo 2003). Abarema cochliacarpos (Gomes) Barneby \& J. W. Grimes (Mimosaceae) is an ornamental and medicinal species that is native to Brazil (USDA 2006).

The mites were mounted in Berlese modified medium (Amrine Jr. \& Manson 1996). Genera identification was based in Amrine Jr. et al. (2003). Measurements are given in micrometers. For females, each measurement of the holotype precedes the corresponding range for the paratypes. Some measurements of paratypes could not be taken because of the orientation of the slide-mounted specimens. For the descriptions of the eriophyid mites presented here, the counts of the ventral opisthosomal annuli starts from the genitalia rear margin and the counts of the dorsal opisthosomal annuli start from the prodorsal rear shield margin.

\section{Acaricalus souzae n. sp. (Fig. 1)}

(Eriophyidae, Phyllocoptinae, Acaricalini)

Diagnosis - Acaricalus souzae is distinctive in the richness of the prodorsal shield ornamentation: median 
line on posterior half of shield, admedian lines delimiting cells and a row of cells extending along the anterior and lateral margin of shield; scapular setae implanted on fleshy tubercles, and the long seta on tibia I (more than three times longer than the segment).

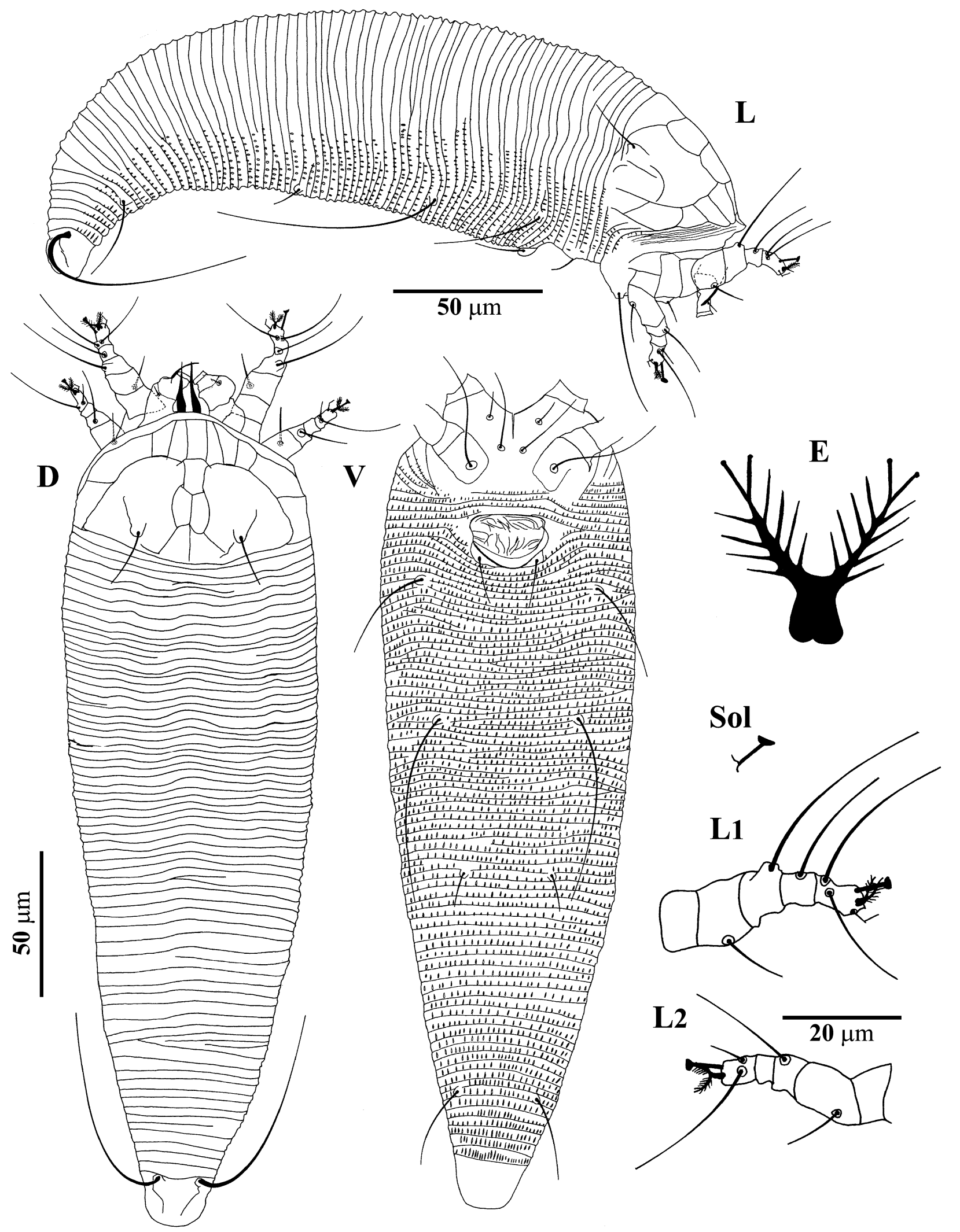

FIGURE 1. Acaricalus souzae n. sp. D - Dorsal habitus of female. V - Ventral habitus of female. L - Lateral habitus of female. L1 — Leg I. L2 — Leg II. E - Empodium (enlarged). Sol — Solenidion. 
Female (Measurements of holotype and range of 5 paratypes) - Body elongate, slightly fusiform, 235 (202-253) long, 71 (58-72) wide. Gnathosoma projecting downwards, 20 (20-25) long; basal seta (ep) 3 (35) long; antapical seta 4 (3-4) long. Chelicerae 14 (14-16) long; oral stylets 10 (9-10) long. Prodorsal shield 44 (37-46) long, 68 (51-68) wide, subpentagonal. Scapular seta (sc) 14 (14-18) long, directed backwards, on fleshy tubercles, placed ahead of rear shield margin, 26 (24-30) apart. Prodorsal shield design of median line on posterior half of shield, admedian lines delimiting cells and a row of cells extending along the anterior and lateral margin of shield. Frontal lobe rounded, broad-based, 4 (3-4) long. Legs with all setae present. Legs I 29 (28-32) long; femur 9 (9-10) long, femoral seta (bv) 9 (8-10) long; genu 5 (5-6) long, genual seta (l”) 29 (27-31) long; tibia 4 (4-6) long, tibial seta $(l ') 18$ (16-20) long; tarsus 5 (5-8) long, lateral seta ( $\left.f t^{\prime \prime}\right) 23$ (2023) long, dorsal seta $\left(f t^{\prime}\right) 16$ (15-16) long, unguinal seta $\left(u^{\prime}\right)$ bifurcate with the proximal segment 2 long and, the longer distal one 3 long and the shorter one minute, solenidion apically well expanded, 5 (5-6) long; empodium divided, 5 (5-6) long, each branch 5-rayed. Legs II 28 (25-28) long; femur 7 (7-10) long, bv 8 (810) long; genu 5 long, $l$ " 14 (13-16) long; tibia 4 (4-5) long; tarsus 5 (5-6) long, ft' 22 (20-23) long, ft' 7 (5$6)$ long, $u$ ' as in leg I with the proximal segment 2 long, the longer distal one 3 long and the shorter one minute, solenidion 6 (6-7) long; empodium as in leg I 5 (5-6) long, each branch 5-rayed. Coxae smooth. Sternal line conspicuous, 8 (8-9) long. Coxal seta I (1b) 8 (6-8) long, 13 (11-16) apart; coxal seta II (1a) 18 (18-23) long, 6 (5-8) apart; coxal seta III (2a) 32 (32-41) long, 23 (20-27) apart; 6 (6-8) coxigenital semi annuli microtuberculated. Genitalia 22 (21-25) wide, 17 (15-18) long; epigynum with two rows of lines; on the proximal (basal) $1 / 3$ lines are oblique and transversal and on the distal 1/3 with 9 (8-10) radial lines; genital seta (3a) 12 (12-16) long. Opisthosoma with 68 (63-75) dorsal annuli, smooth; ventrally with 74 (64-78) annuli, with slightly elongate microtubercles, placed on rear margin of annulus. Dorsal opisthosoma with three faint ridges - a central extending on $3 / 4$ anterior opisthosoma and the lateral extending on anterior half of opisthosoma, except on the first two or three annuli, that are evenly arched. Lateral seta $\left(c_{2}\right) 27$ (27-30) long, in line with 5-6 (5-7) ventral annulus. Ventral seta I (d) 53 (53-67) long, 40 (39-40) apart, 15 (15-20) microtubercles apart, on annulus 22-23 (19-27); ventral seta II (e) 10 (10-13) long, 25 (22-25) apart, 11 (10-12) microtubercles apart, on annulus 44 (39-49); ventral seta III (f) 22 (20-23) long, 22 (20-22) apart, 12 (12-17) microtubercles apart, on annulus 68 (59-72). Caudal seta $\left(h_{2}\right) 48$ (47-60) long; accessory seta $\left(h_{1}\right)$ absent.

Male - Not seen.

Type material - Female holotype and 8 female paratypes, from Ipomoea purpurea (L.) Roth. (Convol-

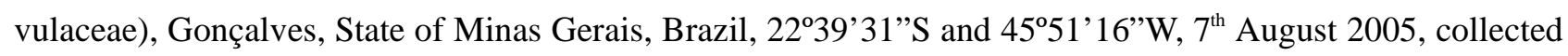
by M. Francisco de Souza Filho, on 4 slides, in the collection of Laboratório de Quarentena Vegetal, Embrapa Recursos Genéticos e Biotecnologia, Brasilia, Distrito Federal and of Instituto Biológico, Campinas, São Paulo, Brazil.

Relation to host - Mites are vagrants, causing no apparent damage.

Etymology - We take pleasure in naming this species after Miguel Francisco de Souza Filho, Entomologist at Centro Experimental do Instituto Biológico (IB-APTA), Campinas, State of São Paulo, Brazil, for his most valuable support in the process of collecting this material.

\section{Aculops fenestratus n. sp. (Fig. 2)}

(Eriophyidae, Phyllocoptinae, Anthocoptini)

Diagnosis - The faint prodorsal shield ornamentation resembling the elongate window of a minaret, the acuminate anterior shield lobe and the smooth dorsoopisthosomal annuli distinguish A. fenestratus.

Female (Measurements of holotype and range of 6 paratypes) - Body fusiform, 186 (181-205) long, 62 (54-62) wide. Gnathosoma projecting downwards, 20 (20-26) long; basal seta (ep) 3 (2-3) long; antapical seta 7 (5-7) long. Chelicerae 19 (18-20) long; oral stylets 13 (13-14) long. Prodorsal shield 35 (34-36) long, 
49 (45-52) wide, subtriangular, design ornated with sinuous faint lines in the anterolateral region; and two admedian lines resembling the outline of an elongate minaret window. Scapular seta (sc) 43 (38-41) long, directed backwards, on tubercles placed on rear shield margin, 24 (20-24) apart. Frontal lobe apically pointed, 6 (5-7) long, 9 (8-9) wide. Legs with all setae present. Legs I 33 (30-34) long; femur 10 (9-11) long, femoral seta (bv) 19 (15-20) long; genu 5 (5-6) long, genual seta (l”) 24 (22-24) long; tibia 7 (6-8) long, tibial seta (l') 7 (6-8) long; tarsus 6 (6-7) long, lateral seta (ft') 23 (22-25) long, dorsal seta (ft') 19 (19-20) long, unguinal seta ( $\left.u^{\prime}\right) 4$ (4-5) long, solenidion 9 (9-10) long; empodium 7 (7-8) long, 6 (6-7)-rayed. Legs II 29 (28-30) long; femur 9 (8-10) long, bv 14 (13-17) long; genu 5 long, l" 12 (9-12) long; tibia 5 (5-6) long; tarsus 6 (5-6) long, $f t^{\prime}$ ' 22 (20-24) long, $f t^{\prime} 7$ (6-8) long, $u$ ' 4 long, solenidion 9 (9-11) long; empodium 8 (7-8) long, 6 (6-7)-rayed. Coxae I ornated with sinuous faint lines and granules; coxae II smooth. Sternal line conspicuous, 7 (5-7) long. Coxal seta I (1b) 11 (11-13) long, 11 (11-13) apart; coxal seta II (1a) 21 (20-28) long, 10 (9-11) apart; coxal seta III (2a) 48 (44-48) long, 22 (20-24) apart; 4 (4-5) coxigenital semi annuli, smooth. Genitalia 22 (21-23) wide, 19 (13-19) long; epigynum with 12 longitudinal lines; genital seta (3a) 20 (19-20) long. Opisthosoma with 41 (38-41) dorsal annuli, smooth; ventrally with 64 (57-64) annuli, with microtubercles slightly elongate, placed on rear margin of annuli. Dorsal opisthosoma flattened. Lateral seta $\left(c_{2}\right) 33$ (28-33) long, in line with 2 (2-5) ventral annulus. Ventral seta I (d) 53 (53-66) long, 37 (36-43) apart, 27 (20-29) microtubercles apart, on annulus 17-18 (15-18); ventral seta II (e) 21 (18-23) long, 21 (20-23) apart, 13 (11-14) microtubercles apart, on annulus 35 (31-35); ventral seta III $(f) 28$ (27-29) long, 20 (19-20) apart, 17 (13-17) microtubercles apart, on annulus 58 (51-58). Caudal seta $\left(h_{2}\right) 83$ (83-98) long; accessory seta $\left(h_{1}\right) 3(3-4)$ long.

Male (Measurements of 4 paratypes) - Smaller than female, 135-166 long, 45-60 wide. Gnathosoma 22-23 long; basal seta (ep) 2-3 long; antapical seta 5 long. Chelicerae 16-19 long; oral stylets 13 long. Prodorsal shield as in female, 33-36 long, 41-49 wide. Scapular seta (sc) 31-36 long, on tubercles 19-23 apart. Frontal lobe 5-8 long, base 8-10 wide. Legs as in female. Leg I 30-32 long; femur 8-10 long, femoral seta (bv) 14-20 long; genu 4-5 long, genual seta (l’) 17-22 long; tibia 6-8 long, tibial seta ( $\left.l^{\prime}\right) 5-8$ long; tarsus 7 long, lateral seta ( $\left.f t^{\prime}\right)$ 19-23 long, dorsal seta $\left(f t^{\prime}\right)$ 14-18 long, unguinal seta $\left(u^{\prime}\right) 4$ long, solenidion 7-10 long; empodium 6-7 long, 6-7-rayed. Legs II 26-30 long; femur 8-10 long, $b v$ 17-24 long; genu 4-5 long, $l$ " 10 long; tibia 4-6 long; tarsus 6 long, ft' 19-21 long, ft' 5-8 long, $u$ ' 4 long, solenidion 7-10 long; empodium 67 long, 6-rayed. Coxae as in female. Sternal line 5-7 long. Coxal seta I (1b) 8-11 long, 10-11 apart; coxal seta II (1a) 20-23 long, 7-9 apart; coxal seta III (2a) 37-45 long, 19-22 apart; 4-6 coxigenital semi annuli, microtuberculated. Genitalia 13-17 wide, 11-13 long, with granules in the lateroposterior area, papillae as figured; genital seta (3a) 11-15 long. Opisthosoma as in female, with 31-35 dorsal annuli; 41-51 ventral annuli. Lateral seta $\left(c_{2}\right)$ 27-31 long, on line with annulus 1-2. Ventral seta I (d) 47-50 long, 28-42 apart, 2326 microtubercles apart, on annulus 11-15; ventral seta II (e) 14-19 long, 13-22 apart, 10-14 microtubercles apart, on annulus 22-29; ventral seta III (f) 20-27 long, 16-18 apart, 14-19 microtubercles apart, on annulus 36-46. Caudal seta $\left(h_{2}\right) 70-84$ long; accessory seta $\left(h_{1}\right) 3-4$ long.

Type material - Female holotype, 36 female and 13 male paratypes, from Delonix regia (Bojer ex. Hook.) Raf. (Fabaceae), Brasília, Distrito Federal, Brazil, 15² $47^{\prime} \mathrm{S}$ and $47^{\circ} 55^{\prime} \mathrm{W}, 6^{\text {th }}$ September 2005, collected by L. Calvoso Miranda, on 10 slides, in the collection of Laboratório de Quarentena Vegetal, Embrapa Recursos Genéticos e Biotecnologia, Brasilia, DF, Brazil and paratypes in the collection of Departamento de Entomologia, Fitopatologia e Zoologia Agrícola, Universidade de São Paulo, ESALQ, Piracicaba, São Paulo, Brazil.

Relation to host - Mites are vagrants, causing no apparent damage.

Etymology - The specific designation, fenestratus, is derived from the Latin fenestra, window, and refers to the prodorsal shield central design.

Remarks - The pointed anterior lobe of the $\mathrm{n}$. sp. resembles that of several other eriophyids in the genus Aculops Keifer, 1966, such as Aculops bolusanthi Meyer \& Ueckermann, 1990 and Aculpos acaciae (Ryke \& 
Meyer, 1960). However, the new species is strikingly distinct in the coxal ornamentation, being ornamented on coxae I and smooth on coxae II. In the other known species both coxae are either ornamented or smooth.

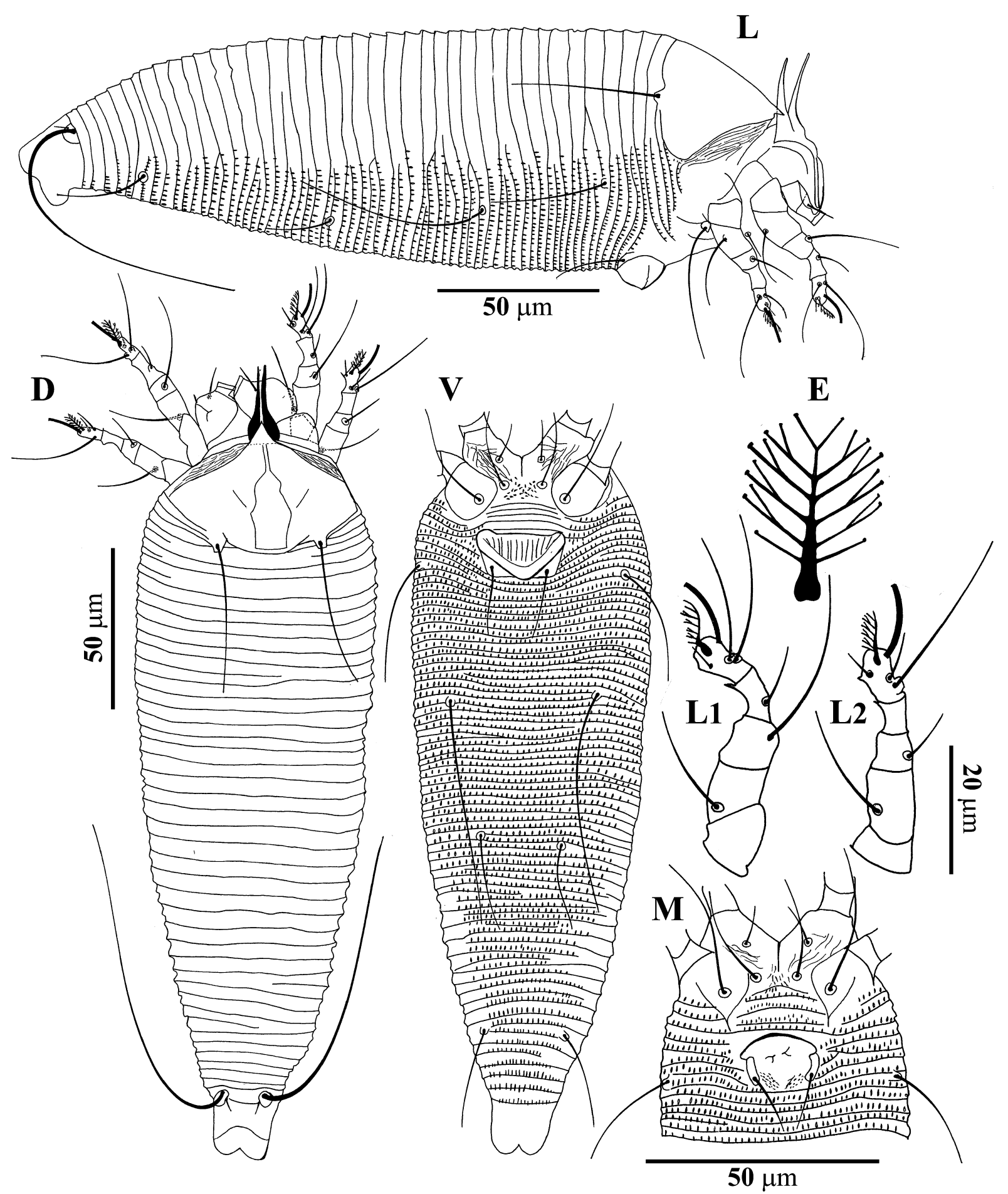

FIGURE 2. Aculops fenestratus n. sp. D - Dorsal habitus of female. V - Ventral habitus of female. L - Lateral habitus of female. M - Coxigenital region of male. L1 - Leg I. L2 - Leg II. E - Empodium (enlarged).

Porcupinotus costaspinosus n. sp. (Fig. 3)

(Eriophyidae, Phyllocoptinae, Anthocoptini)

Diagnosis - Prodorsal shield with an elongate framelike design and a posterior transverse arched line; shield 
with a posterior humplike projection and first three opisthosomal annuli prominent, only visible in lateral view. In a dorsoventral mounting, the posterior shield hump flattens into a posterior shield lobe which also flattens down the first dorso-opisthosomal annuli backwards. These then appear to curve around the shield lobe margin in their central portion. Opisthosoma dorsum with basically five longitudinal ridges made up of a series of uneven, wide based wax-bearing triangular spines. From approximately the eighth to the $23^{\text {rd }}$ dorsal annuli, the median ridge is divided into two longitudinal rows of spines, from approximately the $24^{\text {th }}$ dorsal annulus, the median ridge is once again unique, ending at the $27^{\text {th }}$ annulus.

Female (Measurements of holotype and range of 7 paratypes) - Body fusiform, 187 (180-219) long, 57 (52-65) wide. Gnathosoma projecting downwards, 21 (20-23) long; basal seta (ep) 2 (2-4) long; antapical seta 6 (5-6) long. Chelicerae 18 (18-22) long; oral stylets 16 (15-18) long. Prodorsal shield 41 (37-41) long, 49 (43-49) wide, subhexagonal, slightly ornated with sinuous faint lines in the anterolateral region. Scapular seta (sc) 24 (20-25) long, directed backwards, on elongated tubercles 9 (8-10) long, placed on rear shield margin, 23 (22-24) apart. Prodorsal shield with an elongate framelike design and a posterior transverse arched line; shield with a posterior humplike projection. Frontal lobe apically rounded, broad-based, 5 (5-7) long, 13 (12-13) wide. Legs with all setae present. Legs I 28 (28-31) long; femur 10 (9-10) long, femoral seta (bv) 11 (11-12) long; genu 5 long, genual seta (l’) 21 (21-23) long; tibia 6 (6-8) long, tibial seta (l') 7 (7-9) long; tarsus 6 (6-7) long, lateral seta ( $\left.f t^{\prime \prime}\right) 21$ (18-21) long, dorsal seta ( $\left.f t^{\prime}\right) 17$ (15-17) long, unguinal seta ( $u$ ') 5 (4-5) long, solenidion 7 (7-8) long; empodium 5 (5-7) long, 7- rayed. Legs II 27 (26-28) long; femur 9 long, bv 14 (13-15) long; genu 5 long, l" 11 (9-11) long; tibia 5 (5-6) long; tarsus 5 (5-6) long, ft' 19 (19-21) long, ft' 7 (6-7) long, u' 4 (3-4) long, solenidion 8 (8-9) long; empodium 6 (6-7) long, 7-rayed. Coxae with sinuous faint lines and few granules. Sternal line conspicuous, 6 (6-8) long. Coxal seta I (1b) 10 (9-11) long, 11 (1011) apart; coxal seta II (1a) 22 (22-28) long, 8 (8-9) apart; coxal seta III (2a) 35 (35-41) long, 23 (20-23) apart; 6 (6-7) coxigenital semi annuli, the first ones smooth and the posterior microtuberculated. Genitalia 23 (20-23) wide, 15 (12-15) long; epigynum with granules on the anterior area and a row of 16 longitudinal lines; genital seta (3a) 31 (31-38) long. Opisthosoma with 43 (41-46) dorsal annuli; ventrally with 56 (5366) annuli, first three opisthosomal annuli prominent in lateral view. Opisthosoma dorsum with five longitudinal ridges made of a series of wax-bearing, wide-based, triangular spines. From approximately the eighth to the $23^{\text {rd }}$ dorsal annuli, the median ridge is divided into two longitudinal rows of spines. From approximately the $24^{\text {th }}$ dorsal annulus, the median ridge is again unique, ending at the $27^{\text {th }}$ annulus. Lateral seta $\left(c_{2}\right) 28(26-$ 29) long, in line with 3 (2-3) ventral annulus. Ventral seta I (d) 46 (46-50) long, 43 (40-45) apart, 22 (21-30) microtubercles apart, on annulus 16 (15-21); ventral seta II (e) 15 (15-16) long, 24 (21-25) apart, 13 (11-15) microtubercles apart, on annulus 30-31 (29-38); ventral seta III (f) 24 (23-25) long, 20 (20-22) apart, 13 (1318) microtubercles apart, on annulus 51 (48-61). Caudal seta $\left(h_{2}\right) 89$ (80-91) long; accessory seta $\left(h_{1}\right) 2(2-4)$ long.

Male (Measurements of 5 paratypes) - Smaller than female, 156-174 long, 50-56 wide. Gnathosoma 21-23 long; basal seta (ep) 2-3 long; antapical seta 5-6 long. Chelicerae 18-19 long; oral stylets 14-15 long. Prodorsal shield as in female, 33-38 long, 39-46 wide. Scapular seta ( $s c$ ) 20-22 long, on elongated tubercles 20-21 apart. Frontal lobe 5-8 long, base 10-13 wide. Legs as in female. Leg I 28-31 long; femur 10 long, femoral seta (bv) 12-13 long; genu 4-5 long, genual seta ( $l$ ") 17-23 long; tibia 5-7 long, tibial seta ( $\left.l^{\prime}\right)$ 5-7 long; tarsus 5-7 long, lateral seta $\left(f t^{\prime \prime}\right)$ 18-20 long, dorsal seta $\left(f t^{\prime}\right)$ 14-17 long, unguinal seta $\left(u^{\prime}\right) 4$ long, solenidion 7-8 long; empodium 6-7 long, 7-rayed. Legs II 26-28 long; femur 8-9 long, bv 12-15 long; genu 5 long, $l$ " 9-10 long; tibia 4-5 long; tarsus 5-6 long, $f t$ " 18-20 long, $f t$ ' 5-7 long, $u$ ' 3-4 long, solenidion 8-9 long; empodium 6-7 long, 6-rayed. Coxae I with sinuous faint lines and coxae II with granules. Sternal line 5-8 long. Coxal seta I ( $1 b$ ) 9-11 long, 9-10 apart; coxal seta II ( $1 a$ ) 20-25 long, 7-8 apart; coxal seta III (2a) 33-38 long, 20-23 apart; 7-11 coxigenital semi annuli, microtuberculated. Genitalia 17-19 wide, 12-13 long, with granules, papillae as figured; genital seta (3a) 20-24 long. Opisthosoma as in female, with 41-49 


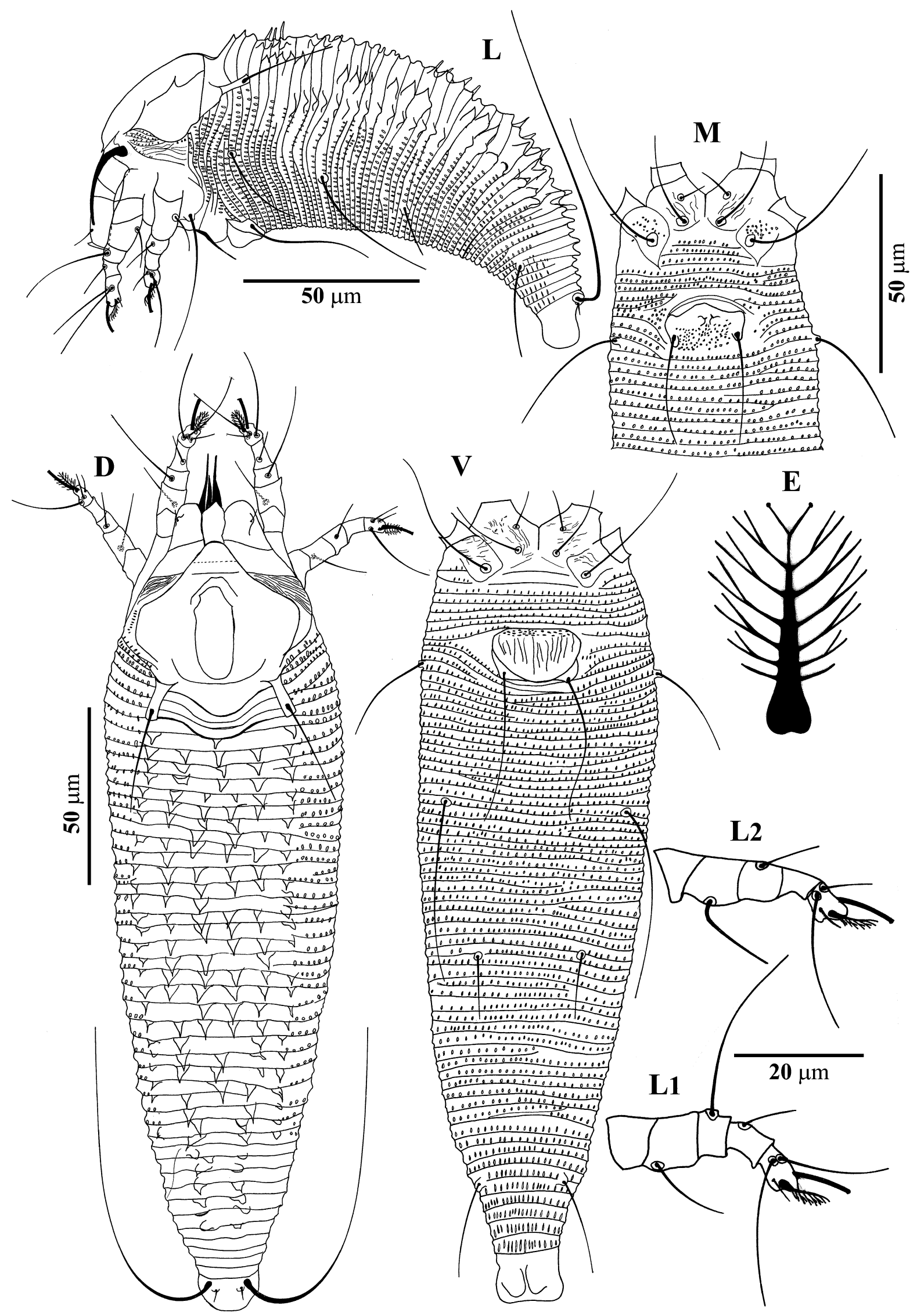

FIGURE 3. Porcupinotus costaspinosus n. sp. D - Dorsal habitus of female. V — Ventral habitus of female. L - Lateral habitus of female. M - Coxigenital region of male. L1 — Leg I. L2 - Leg II. E - Empodium (enlarged). 
dorsal annuli; 45-50 ventral annuli. Lateral seta $\left(c_{2}\right)$ 27-30 long, on line with annulus 1-2. Ventral seta I (d) 41-46 long, 36-41 apart, 18-24 microtubercles apart, on annulus 11-13; ventral seta II (e) 14-17 long, 19-23 apart, 10-14 microtubercles apart, on annulus 24-27; ventral seta III (f), 17-24 long, 19-20 apart, 14-20 microtubercles apart, on annulus 43-49. Caudal seta $\left(h_{2}\right)$ 77-84 long; accessory seta $\left(h_{1}\right) 3$ long.

Type material - Female holotype, 45 female and 16 male paratypes, from Abarema cochliacarpos (Gomes) Barneby \& J. W. Grimes (Mimosaceae), Brasília, Distrito Federal, Brazil, $15^{\circ} 47^{\prime} \mathrm{S}$ and $47^{\circ} 55^{\prime} \mathrm{W}, 6^{\text {th }}$ September 2005, collected by L. Calvoso Miranda, on 11 slides, in the collection of Laboratório de Quarentena Vegetal, Embrapa Recursos Genéticos e Biotecnologia, Brasilia, DF, Brazil and paratypes in the collection of Departamento de Entomologia, Fitopatologia e Zoologia Agrícola, Universidade de São Paulo, ESALQ, Piracicaba, São Paulo, Brazil.

Relation to host - Mites are vagrants, causing no apparent damage.

Etymology - The specific designation is derived from the Latin "costa", rib, ridge, and "spinosus", thorny, in reference to the dorsal opisthosomal ridges made of spines.

\section{Acknowledgments}

To James W. Amrine Jr., WVU, USA, for inestimable colaboration through discussions about taxonomic placement of the Aculops n. sp.. To Letícia Calvoso Miranda, Embrapa Recursos Genéticos e Biotecnologia, Brasília, Distrito Federal, and Miguel Francisco de Souza Filho, Instituto Biológico, Campinas, São Paulo, Brazil for collection of the studied specimens. To Conselho Nacional de Desenvolvimento Científico e Tecnológico $(\mathrm{CNPq})$ for supporting collection costs.

\section{References}

Amrine Junior, J.W. \& Manson, D.C.M. (1996) Preparation, mounting and descriptive study of Eriophyoid mites. In: Lindquist, E.E.; Sabelis, M.W. \& J. Bruin (Org.). Eriophyoid mites: their biology, natural enemies and control. Elsevier, Amsterdam, 383-396.

Amrine Junior, J.W., Stasny, T.A.H. \& Flechtmann, C.H. (2003) Revised keys to world genera of Eriophyoidea (Acari: Prostigmata). Indira Publishing House, West Bloomfield, 244 pp.

Connecticut Botanical Society (2005) Connecticut wildflowers - Common morning glory. Available at www.ct-botanical-society.org/galleries/ipomoeapurp.html, accessed 16 August 2006.

Keifer, H.H. (1966) Eriophyid studies B-21. Bureau of Entomology, California Department of Agriculture, 24pp.

Meyer, M.K.P.S. \& Ueckermann, E.A. (1990) African Eriophyoidea: the genus Aculops Keifer, 1966 (Acari: Eriophyidae). Phytophylactica, 22, 159-175.

Ryke, P.A.J. \& Meyer, M.K.P.S. (1960) The parasitic and predaceous mite fauna (Acarina) associated with Acacia karroo Hayne in the western Transvaal. In: Libro homenaje al Dr. Eduardo Caballero y Caballero, Jubileo 1930-1960. Instituto Politécnico Nacional, Mexico, DF, 559-569.

USDA (2006) Germplasm Resources Information Network - (GRIN) [Online Database].National Germplasm Resources Laboratory, Beltsville, Maryland. Available at www.ars-grin.gov/cgi-bin/npgs/html/taxon.pl?405147, accessed 06 July 2006.

Vozzo, J.A. (2003) Delonix regia (Bojer ex. Hook) Raf. In: Species descriptions, Reforestation, Nurseries and Genetic Resourses Net, USDA, USA. available at www.rngr.net/Publications/ttsm/Folder.2003-07-11.4726, accessed 10 August. 